\title{
The use of Facebook in health education: perceptions of adolescent students
}

\author{
O uso do Facebook na aprendizagem em saúde: percepções de adolescentes escolares
}

El uso de Facebook en el aprendizaje en salud: percepciones de adolescentes en edad escolar

\section{Joyce Mazza Nunes Aragão', Fabiane do Amaral Gubert", Raimundo Augusto Martins Torres", Andréa Soares Rocha da Silva'", Neiva Francenely Cunha Vieira'}

\author{
' Universidade Federal do Ceará, Postgraduate Program in Nursing. Fortaleza, Ceará, Brazil. \\ "Universidade Federal do Ceará, Department of Nursing. Fortaleza, Ceará, Brazil. \\ I" Universidade Federal do Ceará, Department of Physical Therapy. Fortaleza, Ceará, Brazil.
}

\section{How to cite this article:}

Aragão JMN, Gubert FA, Torres RAM, Silva ASR, Vieira NFC. The use of Facebook in health education: perceptions of adolescent students. Rev Bras Enferm [Internet]. 2018;71(2):265-71. DOI: http://dx.doi.org/10.1590/0034-7167-2016-0604

\section{Submission: 11-12-2016 Approval: 04-11-2017}

\begin{abstract}
Objective: understand the perceptions of adolescent students regarding the use of Facebook social media in sexual and reproductive health learning in the Family Health Strategy. Method: a qualitative, descriptive study developed with 96 adolescents from a public school and a private school in Fortaleza-CE who concluded an educational intervention using Facebook. The information was collected in the online environment itself, as well as in a questionnaire applied in person. For the collection and analysis of this information, netnography was used. Results: Facebook contributed to the sexual and reproductive health education in an interactive, playful and practical way, reducing the embarrassment of some adolescents to converse on the subject, and brought adolescents closer to the health service, by strengthening their bond with Health professionals. Final considerations: health professionals should recognize that such virtual spaces on the Internet offer potential for the production of health care, especially among adolescents.
\end{abstract}

Descriptors: Nursing; Family Health Strategy; Health Education; Adolescent Health; Sexual Health.

\section{RESUMO}

Objetivo: compreender as percepções de adolescentes escolares acerca do uso da mídia social Facebook na aprendizagem em saúde sexual e reprodutiva, na Estratégia Saúde da Família. Método: estudo qualitativo, descritivo, desenvolvido com 96 adolescentes de uma escola pública e outra particular de Fortaleza-CE que concluíram uma intervenção educativa mediada pelo Facebook. As informações foram coletadas no próprio ambiente on-line, bem como em um questionário aplicado presencialmente. Para coleta e análise dessas informações, utilizou-se a netnografia. Resultados: o Facebook contribuiu para o aprendizado em saúde sexual e reprodutiva, de maneira interativa, lúdica e prática, amenizando a vergonha de alguns adolescentes para dialogar sobre a temática, e aproximou os adolescentes do serviço de saúde, mediante o fortalecimento do vínculo com os profissionais de saúde. Considerações finais: os profissionais de saúde devem reconhecer que esses espaços virtuais na Internet podem ser territórios de produção do cuidado em saúde, especialmente com adolescentes.

Descritores: Enfermagem; Estratégia Saúde da Família; Educação em Saúde; Saúde do Adolescente; Saúde Sexual.

\section{RESUMEN}

Objetivo: comprender las percepciones de adolescentes en edad escolar acerca del uso del medio de comunicación social Facebook en el aprendizaje en salud sexual y reproductiva, en la Estrategia Salud de la Familia. Método: estudio cualitativo, descriptivo, desarrollado con 96 adolescentes de una escuela pública y otra particular de Fortaleza-CE que concluyeron una intervención educativa mediada por Facebook. Las informaciones fueron colectadas en el propio ambiente on-line, bien como en un cuestionario aplicado presencialmente. Para colecta y análisis de esas informaciones, se utilizó la netnografia. Resultados: Facebook contribuyó para el aprendizaje en salud sexual y reproductiva, de manera interactiva, lúdica y práctica, aliviando la vergüenza de algunos adolescentes para dialogar sobre la temática, y aproximó los adolescentes del servicio de salud, mediante el fortalecimiento del vínculo con los profesionales de salud. Consideraciones finales: los profesionales de 
salud deben reconocer que esos espacios virtuales en Internet pueden ser territorios de producción del cuidado en salud, especialmente con adolescentes.

Descriptores: Enfermería; Estrategia Salud de la Familia; Educación en Salud; Salud del Adolescente; Salud Sexual.

\section{CORRESPONDING AUTHOR Joyce Mazza Nunes Aragão E-mail: joycemazza@hotmail.com}

\section{INTRODUCTION}

At the present time, the Internet is a virtual territory that has a continuous and accelerated presence among the youngest part of the population. Throughout the world, children and young people enjoy unprecedented opportunities to connect with each other and share experiences and information. Some 10 million adolescents around the world make daily use of the Internet, their main activities are linked to social networks, entertainment and the search for information ${ }^{(1)}$. In Brazil, the "TIC Domiciles" [Information and Communication, Technology in Homes] survey, in 2013, reported that $75 \%$ of adolescents between the ages of 10 and 15 and $77 \%$ of young people between the ages of 16 and 24 are Internet users and that the higher the family income, the greater their access to the network ${ }^{(2)}$.

This reality favors the use of Digital Information and Communication Technologies in health education practices with adolescents, especially social networks such as Facebook, Twitter, Instagram etc. ${ }^{(3)}$. These technologies can also be used to discuss issues of sexual and reproductive health, given that adolescence is a phase of life exposed to various situations of vulnerability related to the onset of sexual activity.

Promoting strategies that provide knowledge about sexual and reproductive health for adolescents is essential for healthy sexuality, in order to overcome the barriers and difficulties of the family and school in addressing issues related to sexuality. Consequently discussions on this theme are often superficial, thus the importance of the role of health professionals in adolescent sexual education and the strengthening of the family and school relationship ${ }^{(4)}$.

Despite the current public policies, it has been a challenge for health professionals, especially the nurse, who is one of the main implementers of the School Health Program, to promote access and participation of adolescents in clinical and educational Health actions, especially in the Family Health Strategy (FHS). Health professionals recognize that there are difficulties in developing activities that arouse the attention of this public, motivating them to participate in activities proposed by the health services ${ }^{(5)}$.

In this sense, for the educational process, health professionals can use online social networks to expand health knowledge, facilitating individual learning from interactivity with the collective, in a playful and interesting way for the young person. In addition, these media contribute to overcome limitations of time and space, allowing a greater range of subjects that can interact at any time and in any place, thereby breaking with fixed times for learning.

Studies have shown that Facebook is a social network that can be used as a virtual learning environment (VLE) ${ }^{(6-7)}$. An international study has reported that new digital media (Internet, text messaging and social networking sites) offer innovative tools for sexual health interventions among adolescents, as they have drastically changed communication between people around the world, favoring dialogue on issues which could be more difficult to address on a face-to-face basis ${ }^{(8)}$.

Associated with the use of social networks, the school is a privileged space for actions to promote health because it congregates adolescents ${ }^{(9-10)}$, as such it should be valorized by health professionals. In the literature there are countless positive experiences of educational practice in public schools, whether with the realization of workshops, dynamics, use of educational games, or with other technologies; however, surveys conducted in private schools and with social networks such as Facebook as a scenario are still relatively scarce ${ }^{(11-12)}$.

From the foregoing, the following question emerges: is it possible that the nurse, as a member of the family health team, can use the Facebook social network as a VLE, with Brazilian adolescents attending public and private schools, to promote sexual and reproductive health?

Faced with this question, an educational intervention via the online social network Facebook was developed as a means of (re) signification of knowledge, attitudes and practices of adolescents, on sexual and reproductive health, using digital learning as an attractive element with easy access to this young population.

Based on the above experience, this study was performed with the objective of understanding the perceptions of school adolescents on the use of Facebook social media in sexual and reproductive health learning.

\section{METHOD}

\section{Ethical aspects}

The study was guided by Resolution $466 / 12^{(13)}$ and obtained approval of the Research Ethics Committee at the Federal University of Ceará. The anonymity of the adolescents was guaranteed; they were identified only by their gender and type of school in which they studied, i.e. an adolescent public school student (PUAS) or attending a private school (PRAS).

Obtaining information about the use of Facebook in health learning, collected in the Facebook groups and/or their profiles was authorized by the participating adolescents, after explaining the objectives of the study. The adolescents and their guardians signed the Terms of Free and Informed Consent for adolescents.

On Facebook, each participant can manage and control their privacy and security settings by owning all the information and content they post, then defining how it will be shared.

\section{Type of study}

Descriptive research with a qualitative approach into the perceptions of school adolescents about their use of Facebook in sexual and reproductive health learning. 


\section{Methodological procedures}

Data collection took place in August 2015, following the completion of a six-week social media-mediated educational intervention between May and June 2015. For this intervention, 135 adolescents were enrolled voluntarily attending a public and a private school. They were placed in the three closed (secret) groups, that is, groups that are impossible to be accessed by other people, created specifically for the educational intervention. However, 96 out of the 135 concluded the intervention, of which: 28 students attending a private school; and 68 students a public school in 2 groups on Facebook.

In this online social network, the groups have discussion environments, posting of files, videos, photographs and creation of events. They were conducted by the researcher / facilitator who is also an FHS nurse in the neighborhood where the adolescents study and mostly reside.

The public school operates from 7:00 a.m. to 9:30 p.m., and was inaugurated in 1986. It has ten classrooms, a teacher's room, among other support facilities, a library linked to the computer lab, which is equipped with 20 computers with access to broadband internet. The private school founded its headquarters in 1997, with excellent physical structure, sports court, large air-conditioned classrooms, dining rooms, library and video room for educational activities, working in the morning and afternoon periods.

The themes that guided the educational intervention on Facebook were: Adolescent Health Promotion; Sexuality and Gender; The body that gets sick - STDs / HIV / AIDS; The body that reproduces itself - Pregnancy in Adolescence; and Safer sex. The content used included publications from the Ministries of Health and Education that indicate educational technologies and media (videos, booklets, among others) to work with adolescents in sexual and reproductive health education ${ }^{(14)}$.

These technologies and educational media were used as triggers for discussions in the forums of Facebook, arousing the attention of the adolescent in an attractive and not tiresome manner. All these posts were based on provocative and short phrases or questions, using a simple language appropriate to the reality of adolescents and were associated with images that illustrate the theme.

As the topic of sexual and reproductive health is covered with taboos, beliefs, shyness and shame on the part of the adolescents, it was possible to use inbox messages, allowing them to secretly ask the nurse questions; because some adolescents could be too embarrassed to ask questions in front of colleagues, even on the Facebook platform.

During this period, three face-to-face meetings were also held in each of the schools, according to the previous planning of the participants, with the first meeting held at the beginning of the intervention, the second in the middle of the period and the third at the end of the educational intervention.

\section{Study scenario}

The study consisted of two environments where the adolescents congregated: cyberspace, represented by Facebook as an empirical field of research, and the schools where they studied, one private and the other from the state public network. The schools were selected because they offer Primary and Secondary
Education and are located in the region attended by a Primary Health Care Unit in a suburb of Fortaleza-CE, where the Human Development Index was 0.22, ranking 96th position among the 119 districts of the municipality ${ }^{(15)}$. In addition, it is characterized by a high pregnancy rate in adolescence. The public school is a member of the School Health Program.

\section{Data source}

Participating in the study were 96 adolescents, 45 males and 51 females, who concluded an educational intervention mediated by Facebook. They attended the 9th year of elementary school or the first year of high school and were on average 15 years of age. In the public school, the greater participation was with females (39), while in the private school, it was males (16).

\section{Collection and organization of data}

At the end of the educational intervention, we sought to understand the perception of adolescents involved in the use of the social network Facebook, for educational purposes in sexual and reproductive health.

For this, the students were able to express themselves in the online environment, via discussion forums, as well as through an interview held in the third and then final face-to-face meetings, which contained open questions such as: Tell me a little about your experience in participating in a Facebook group to discuss sexual and reproductive health with the nurse?; What is your opinion about using Facebook for sexual and reproductive health education with adolescents?; and After the Facebook group started, did you feel more motivated to attend a health service?

\section{Data analysis}

For the collection and analysis of information, netnography was used, which is an observational research based on on-line fieldwork; this uses computer-mediated communications as a source of data to arrive at the understanding and ethnographic representation of a cultural or communal phenomenon ${ }^{(16)}$.

Netnography is a participatory observational research; thus, it provides for the immersion and involvement of the researcher within the social group studied, as seen in the present study. In this sense, data collection does not occur in isolation from the analysis and includes data from the researcher's interaction with the group members and data from field notes, in which the researcher records his or her own observations, as well as pre-existing archival data, in which the researcher is not directly involved ${ }^{(16)}$.

This information was analyzed according to the netnography referential, highlighting the main findings and grouped into subtopics: Facebook as an environment for learning in sexual and reproductive health; The practicality of learning through Facebook; Chatting on Facebook is not "embarrassing"; and Facebook has brought teenagers closer to the health service.

\section{RESULTS}

Facebook as an environment for learning in sexual and reproductive health

For adolescents, their interaction in the online environment favored the sharing of knowledge and experiences about sexual 
and reproductive health with both peers and the nurse. Overall, all the comments were positive, with emphasis on collective learning, dynamic, facilitator and innovative, contributing to the clarification of common questions inherent to adolescence.

The adolescents also recognize that they are multipliers of the knowledge acquired in the Facebook group, since they can pass on the information taught to their peers.

Because we had never learned things as you are learning now and we can teach others, by interacting more with people. (PUAS)

I think it was really cool, so far I've learned many things that were not even in my head. (PRAS)

I loved it because I was able to clarify all issues as a teenager, thanks to this group. Today I know that having sex without a condom can bring several risks to my health. I hope you do not remove this group from Facebook. Thank you, Auntie. (PUAS)

Attention has been drawn to the discourse of a teenager who says she did not comment on some of the group's posts, but nevertheless has never failed to keep up with educational activities in the online environment, learning and clarifying questions.

Well, I loved to participate, I clarified my questions and I learned, I may not have commented on some publications, but I certainly never stopped accompanying everything and learning a lot. (PUAS)

The students of the private school also affirmed that these initiatives should be encouraged in their school, since they contributed to their acquired learning, because according to the group, the educational activities in private schools as developed by the FHS are still limited.

It was very good to ask questions and clarify what I did not know about STDs, condom use, etc. I think there should be more initiatives like yours, thanks for this opportunity. (PRAS)

\section{The practicality of learning through Facebook}

The adolescents emphasized the convenience and ease of access to Facebook, given that this form of communication is widely known and used among them, it facilitated learning about sexual and reproductive health in the context of adolescence.

They felt motivated to participate in the group discussions, because they could clarify their questions at any time they needed.

Teenagers are more computer-focused, and people are more motivated, because they have access to information, because you can ask questions when you want, just ask. (PRAS)

I found it very cool, more practical to pass on the teachings to teenagers, because most teenagers access Facebook and can learn more about it and pass it on to other people. (PUAS)

It's a lot easier and more practical to learn because young people spend half the time on social networks and it's important that they learn about sexual health. (PRAS)
Other students, in addition to learning in the Facebook group, acquired in a relaxed and dynamic manner, affirmed that their participation enabled meeting different people, interacting and making new friendships.

I liked it a lot, learned things I did not know and that were important, which led me to be more aware and helped me meet cool people. Thank you for this great experience. (PUAS)

I loved this experience, it was very good, I did not know that on Facebook I would learn so much I did not know was important and meet people like you, Auntie. It was really cool. (PUAS)

\section{Chatting on Facebook is not "embarrassing"}

The adolescents recognize that shyness and shame to discuss sexual and reproductive health, present at this stage of life, can be minimized via an online environment. They say that in the Facebook group they felt more at ease to talk about embarrassing issues.

On the other hand, they often have no one to answer their questions, since many parents are too ashamed to talk about these matters with their children. These findings emphasize the relevance of the discussion on sexual and reproductive health with adolescents.

I liked it a lot, because Facebook is not so embarrassing and many people are curious about it. (PRAS)

With Facebook, the conversations were really cool, and sometimes we do not have anyone to ask questions about, and here we have the freedom to ask the things we are embarrassed about. (PUAS)

I thought it was really cool, because a lot of parents are embarrassed to talk to their children. (PUAS)

\section{Facebook enabled proximity between adolescents and the} health service

The interaction in this online environment between adolescent student and the FHS nurse favored the creation of bonds and trust, thereby minimizing fear and motivating the majority of adolescents to seek attendance at their local health center.

Facebook has made teens lose their fear of going to the health clinic because the person ends up creating a certain intimacy with the nurse, because it is a very intimate affair. (PRAS)

Facebook is a means of communication that can bring people closer and make it easier, because I got good information, and that motivates each of the teenagers, because we end up creating a bond with the health workers. (PRAS)

As both [nurse and students] communicate every day, talking more about it, and interacting more with people, it encourages and the teenager feels more comfortable. (PUAS)

However, one teenager considered that the initiative to seek a health service does not only depend on the approximation, 
interaction and creation of bonds with health professionals, but also on the individual interest of each adolescent.

It brings us more or less closer, because there are people who are interested, but there are others who are not. (PUAS)

\section{DISCUSSION}

The experience of adolescent students with the use of Facebook for sexual and reproductive health learning was reported with an emphasis on the acquired learning, through interaction with their peers and the FHS nurse, in a dynamic, participatory and innovative manner.

Another study showed that the use of social media aimed at sex education in the school context contributed to increasing the knowledge of young people about sexual health and, therefore can be a practical complement to face-to-face classes, while integrating teachers and health professionals ${ }^{(17)}$.

The adolescents in the study recognize the practicality and ease with which Facebook can be used for sexual and reproductive health learning, since they are already faithful users who dominate the skills for this technology.

Facebook contributes to the ease of understanding of students already inserted in the digital world; as such, learning becomes pleasant, contributing to an increase in their autonomy, seeking to know what is relevant and at the same time interesting and fundamental in today's society ${ }^{(7)}$.

In the educational field, a study has shown that the use of Facebook has great potential, allowing group work, interactive sharing of classes, favoring increased curiosity and motivation on the topics covered, as well as providing links to texts, videos and other directions of collective interest ${ }^{(18)}$.

For the adolescents in the study, chatting via Facebook is not "embarrassing", so they feel more at ease to discuss and share experiences with colleagues and / or nurses on sensitive issues regarding sex and sexuality. Even the most timid students in faceto-face meetings were observed to have online conversations with peers and / or nurses, albeit privately through social media chat.

Adolescents consider the Internet to be a means of connecting with the world, indispensable in everyday life, and relationships in social networks function as an extension of face-to-face relationships. Thus, these youngsters, for the most part, effectively believe that in many situations of social interaction, it is easier to resort to online communication rather than face-to-face communication ${ }^{(19)}$.

It has already been shown that Facebook participants for educational purposes feel more "at ease" to communicate in a private group on Facebook than in the classroom, suggesting a view that this platform provides the collaborative creation of a space for interaction, which is beyond the confines of the usual social or formal classroom setting ${ }^{(20)}$.

In another study, the more timid students were able to ask questions and participate actively in the discussions in the online groups; those who were more inattentive could keep up with everything that was happening, since the content was permanently available and could be seen and revised according to their individual needs ${ }^{(21)}$.
The proximity between nurse and teenagers has strengthened bonds of friendship and trust, including schools, favoring learning about sexual and reproductive health in the context of adolescence. Additionally, according to the participating adolescents, this strategy collaborated with their approaching the health service.

In this perspective, the use of Facebook in health education practice is not limited to a mere question-and-answer space and in the sharing of files for learning, but, by surpassing the barriers of health services, it contributes significantly to the construction and strengthening of links between these adolescents and the health professionals.

Thus, it has been confirmed that Internet social media can be used as pedagogical tools by the FHS nurse. This corroborates a study that demonstrated they not only helped to improve and broaden the learning possibilities of the students, but also offered the educator other ways of relating and interacting with students, narrowing the relationship and broadening the learning space, allowing them to even become responsible for their own learning ${ }^{(22)}$.

Within the scope of the SUS [Unified Health System], the FHS is essential for the reorganization of basic health care, providing for collective actions and reconstruction of health practices on an inter-discipline and inter-sector basis for a specific territory ${ }^{(23)}$.

In this perspective, the partnership with public and private schools present in the scope of the FHS is essential, since it is a privileged space for health promotion practices and prevention of health and disease aggravations, and it is essential that health professionals value and expand actions to promote sexual health ${ }^{(10)}$.

In view of the above, it is understood that discussing sexual and reproductive health with school adolescents should be something interesting and meaningful for those involved, promoting participation and stimulating the teenager to think creatively, because it is a topic that involves issues such as: shame, taboos, myths, and religious beliefs. Thus, the educational strategies used with adolescents should be dynamic, participative and interactive in order to stimulate the participation of this audience, rendering the teaching-learning process something endowed with meaning and joy.

The use of social media contributes to the achievement of these goals, as they are part of the daily life of adolescents, enabling social interaction and pleasure; so they can be used in health education practices, provided that it is planned and directed, with intentional mediation by the health professional.

\section{Study limitations}

The limitations of Internet access and connectivity mentioned by the adolescents of both schools, especially in the public schools, and the absenteeism of the public school students in the face-to-face meetings, which interfered in the collection of information.

\section{Contributions to public health and Nursing}

The findings of the study revealed the relevance and necessity of educational health interventions among adolescents from public and private schools present in the FHS, showing, mainly, that Facebook social media can be used by health professionals. This form of educational practice contributes to health education by engaging the interest and interactivity of 
adolescents, besides overcoming geographical distances and bringing them closer to the health service.

From this perspective, it is necessary for health professionals to recognize that virtual environments, such as online social networks, are potential territories for the promotion of health care, especially in the FHS, given their proximity to the social context in which the subjects live, work or study.

\section{FINAL CONSIDERATIONS}

The perceptions of school adolescents about the use of social media Facebook in sexual and reproductive health education were positive, with emphasis on the knowledge acquired and the practicality of this social network, since many are already assiduous users of this environment, which favored the bond between all participants. They also highlight that there was an approximation between adolescents, health professionals, primary health care services and the FHS.

It is important to underscore that the nurse as a health educator plays a significant role in the sexual and reproductive health of adolescents. He or she is an agent that transforms reality when planning and performing activities that favor discussion, exchange of experiences, debate, reflection and modification of the attitudes of adolescents; while also acting as an articulator for members of the health, family and school staff.

In this perspective, the school, whether public or private, is an appropriate space for the implementation of educational programs, taking into account the participation of peers and friends in these actions. Thus, this study reaffirms that it is possible and necessary to "go where young people are", that is, to seek to enter the adolescents' world, as characterized by different configurations and productions of the senses of each generation, making it possible to understand how knowledge can enter in dialogues, through these new practices of virtual learning arising from use of the Internet.

The present authors suggest the need to carry out further studies into the use of other forms of social media in educational health practice and for various population groups. This brings to the forefront the use of Digital Information and Communication Technologies for discussion among health workers, in order to optimize this practice by the discovery of new fields of professional activity.

\section{REFERENCES}

1. UNICEF. Fundo das nações unidas para a infância. O uso da internet por adolescentes[Internet]. Brasília, DF: UNICEF. 2013[cited 2016 Oct 10]. Available from: http://www.unicef.org/brazil/pt/br_uso_internet_adolescentes.pdf

2. Comitê Gestor da Internet no Brasil. Pesquisa TIC Domicílios 2013: pesquisa sobre o uso das tecnologias de informação e comunicação no Brasil. São Paulo: Comitê Gestor da Internet no Brasil [Internet]. 2014[cited 2016 Oct 10]. Available from: http:// www.cetic.br/media/docs/publicacoes/2/TIC_DOM_EMP_2013_livro_eletronico.pdf

3. Seabra C. Tecnologias na escola. Porto Alegre: Telos Empreendimentos Culturais, 2010.

4. Nery IS, Feitosa JJ, Sousa AF, Fernandes AC. Approach to sexuality in the dialogue between parents and adolescents. Acta Paul Enferm [Internet]. 2015[cited 2016 Oct 10];28(3):287-92. Available from: http://www.scielo.br/pdf/ape/v28n3/1982-0194ape-28-03-0287.pdf

5. Queiroz MVO, Lucena NBF, Brasil EGM, Gomes ILV. Cuidado ao adolescente na atenção primária: discurso dos profissionais sobre o enfoque da integralidade. Rev Rene [Internet]. 2011[cited 2016 Oct 10];12(n.esp.):1036-44. Available from: http://www. revistarene.ufc.br/vol12n4_esp_pdf/a20v12esp_n4.pdf

6. Ferreira JL, Correa BRPG, Torres PL. O uso pedagógico da rede social Facebook. Rev Dig CVA-RICESU [Internet]. 2012 [cited 2016 Oct 10];7(28). Available from: http://pead.ucpel.tche.br/revistas/index.php/colabora/article/view/199/152

7. Bona AS. Espaço de aprendizagem digital da matemática: o aprender a aprender por cooperação. [Tese]. [Internet]. Universidade Federal do Rio Grande do Sul. Centro de Estudos Interdisciplinares em novas tecnologias na Educação. Programa de Pósgraduação em Informática na Educação: Porto Alegre - RS; 2012[cited 2016 Oct 10]. Available from: http://www.lume.ufrgs.br/ bitstream/handle/10183/63132/000869248.pdf?sequen

8. Guse K, Levine D, Martins S, Gaarde ALA J, Westmorland W, Gilliam M. Interventions using new digital media to improve adolescent sexual health: a systematic review. J Adolesc Health [Internet]. 2012[cited 2016 Oct 10];51:535-43. Available from: http://www.jahonline.org/article/S1054-139X(12)00135-8/pdf

9. Santos AAG, Silva RM, Machado MFAS, Vieira LJES, Catrib AM, Fontenelle J, et al. The meaning that health professionals attribute to promotion of the health of adolescents. Ciênc Saúde Colet [Internet]. 2012[cited 2016 Oct 10];17(5):1275-84. Available from: http://www.scielo.br/pdf/csc/v17n5/a21v17n5.pdf

10. Araújo AC, Lunardi VL, Silveira RS, Thofehrn MB, Porto AR, Soares DC. Implicações da sexualidade e reprodução no adolescer saudável. Rev Rene [Internet]. 2012[cited 2016 Oct 10];13(2):437-44. Available from: http://www.periodicos.ufc.br/rene/article/ download/3951/3127

11. Viero VSF, Farias JM, Ferraz F, Simões PW, Martins JA, Ceretta LB. Educação em saúde com adolescentes: análise da aquisição de conhecimentos sobre temas de saúde. Esc Anna Nery Rev Enferm[Internet]. 2015[cited 2016 Oct 10];19(3):484-90. Available from: http://www.scielo.br/pdf/ean/v19n3/1414-8145-ean-19-03-0484.pdf 
12. Baumfeld TS, Sá RB, Santos DFA, Monteiro OM, Ferreira MB, Silva EMV, et al. Autonomia do Cuidado: interlocução afetivo sexual com adolescentes no PET-Saúde. Rev Bras Educ Méd[Internet]. 2012[cited 2016 Oct 10];36(Supl.1):71-80. Available from: http:// www.scielo.br/pdf/rbem/v36n1s1/v36n1s1a10.pdf

13. Brasil. Conselho Nacional de Saúde. Resolução nº 466 de 12 de dezembro de 2012. Brasília, 2012.

14. Brasil. Ministério da Saúde. Ministério da Educação. Guia de sugestões de atividades: Semana saúde na escola. [Internet]. Brasília; 2013[cited 2016 Oct 10]. Available from: http://189.28.128.100/dab/docs/portaldab/documentos/GUIA_DE_SUGESTOES_DE_ ATIVIDADES_SSE_2013.pdf

15. Fortaleza. Secretaria Municipal de Desenvolvimento Econômico. Desenvolvimento Humano, por bairro, em Fortaleza. Fortaleza. Secretaria Municipal de Desenvolvimento Econômico [Internet]. 2010[cited 2016 Oct 10]. Available from: http://dados.fortaleza. ce.gov.br/dataset/desenvolvimento-humano-por-bairro-de-fortaleza

16. Kozinets RV. Netnografia: realizando pesquisa etnográfica online. Bueno D.(Trad.). Porto Alegre: Penso, 2014.

17. Costa AM. Por trás dos links, sempre existem pessoas: o anonimato como fator de pertencimento no uso de redes sociais on-line em projetos educacionais. [Tese]. [Internet]. Universidade Federal do Rio Grande do Norte. Centro de Ciências Sociais Aplicadas. Centro de Educação. Natal (RN), 2013. Available from: http://repositorio.ufrn.br:8080/jspui/handle/123456789/14458

18. Alves TP, Araújo RKS. Moodle e o Facebook Como Espaços Pedagógicos: percepções discentes acerca da utilização destes ambientes. TEIA[Internet]. 2013[cited 2016 Oct 10];4(2):1-16. Available from: http://www.repositorios.ufpe.br/revistas/index.php/ emteia/article/view/2234

19. Assunção RS, Matos PM. Perspectivas dos adolescentes sobre o uso do Facebook: um estudo qualitativo. Psicol Estud[Internet]. 2014[cited 2016 Oct 10];19(3):539-47. Available from: http://www.scielo.br/pdf/pe/v19n3/a18v19n3.pdf

20. Ferreira GMS, Bohadana EDB. O Facebook na Educação: um novo sujeito? REEDUC [Internet]. 2014[cited 2016 Oct 10];11(25):11241. Available from: http://periodicos.estacio.br/index.php/reeduc/article/view/944/503

21. Gama Neto EM, Porto CM, Teixeira Júnior VA, Vale LC. Pensar, fazer e compartilhar: a construção cooperativa entre aluno e professor no Facebook. Interfaces Científic Educ[Internet]. 2013[cited 2016 Oct 10];2(1):93-101. Available from: http://openrit. grupotiradentes.com/xmlui/handle/set/394

22. Costa AMSN, Ferreira ALA. Novas possibilidades metodológicas para o ensino-aprendizagem mediados pelas redes sociais twitter e Facebook. REnCiMa [Internet]. 2012[cited 2016 Oct 10];3(2):136-47. Available from: http://revistapos.cruzeirodosul.edu.br/ index.php/rencima/article/viewFile/494/413

23. Brasil. Ministério da Saúde. Secretaria de Atenção à Saúde. Departamento de Atenção Básica. Instrutivo PSE. Brasília: Ministério da Saúde [Internet]. 2011[cited 2016 Oct 10]. Available from: http://189.28.128.100/dab/docs/legislacao/passo_a_passo_pse.pdf 